\title{
GERAKAN AYO PAKAI MASKER, BERSAMA MELAWAN COVID-19 DI DESA MLAJAH KECAMATAN BANGKALAN KABUPATEN BANGKALAN
}

\author{
Nurun Nikmah ${ }^{1}$, Novi Anggraeni ${ }^{2}$ \\ ${ }^{1,2}$ Pendidikan Profesi Bidan; Kebidanan; Sekolah Tinggi Ilmu Kesehatan Ngudia Husada Madura; \\ Jl. RE Martadinata No 45 Bangkalan \\ e-mail: nurunx@yahoo.co.id
}

$\begin{array}{ll}\text { Naskah di terima } & : 16 / 03 / 21 \\ \text { Naskah di revisi } & : 24 / 04 / 21 \\ \text { Naskah di setujui } & : 05 / 07 / 21\end{array}$

\begin{abstract}
Abstrak
Langkah pencegahan dan upaya pengendalian yang bisa dilakukan untuk membatasi dan menekan penyebaran virus saluran pernapasan termasuk Covid 19 dilakukan dengan penggunaan masker. Masker bisa digunakan untuk melindungi baik orang sehat maupun orang sakit, melindungi diri sendiri agar tidak tertular dan menularkan. Metode dalam kegiatan pengabdian masyarakat ini yaitu dalam berupa: Pemberian Pemberian Edukasi tentang pentingnya masker, pemberian masker, dan bagaimana penggunaan masker yang tepat. Berdasarkan hasil pengamatan yang telah dilakukan di Perumahan Griya Anugerah Desa Mlajah Kecamatan Bangkalan pada September disimpulkan bahwa terdapat perubahan jumlah pengetahuan dan perilaku dalam penggunaan masker pada balita. Pencegahan penularan penyakit Covid 19 dilakukan dengan cara peningkatan pengetahuan ibu tentang pentingnya penggunaan masker pada anak, dengan cara pemberian pengetahuan tentang pentingnya penggunaan masker, dan dengan pemberian masker kepada anak dengan cara door to door.
\end{abstract}

Kata kunci- Masker, Covid 19

\begin{abstract}
Prevention and control measures that can be taken to limit and suppress the spread of respiratory viruses including Covid 19 are carried out by using masks. Masks can be used to protect both healthy people and sick people, protect yourself from being infected and transmitting. The methods in this community service activity are in the form of: Giving Education about the importance of masks, giving masks, and how to use masks properly. Based on observations made at Griya Anugerah Housing, Mlajah Village, Bangkalan District in September, it was concluded that there was a change in the amount of knowledge and behavior in the use of masks in toddlers. Prevention of transmission of the Covid 19 disease is carried out by increasing mother's knowledge about the importance of using masks in children, by providing knowledge about the importance of using masks, and by giving masks to children by door to door.
\end{abstract}

Keywords-Masks, Covid 19 


\section{PENDAHULUAN}

2.

Penggunaan masker adalah suatu upaya untuk pencegahan penularan Covid 19 serta menekan menyebarnya virus saluran pernapasan termasuk Covid 19. Perlindungan terhadap tertularnya maupun menularkan virus bisa dilakukan dengan menggunakan masker.

Covid 19 merupakan salah satu penyakit saluran pernapasan yang bisa terjadi dengan gejala dan tanpa gejala. Beberapa orang dilaporkan terinfeksi virus Covid 19 sama sekali tidak mengalami suatu gejala. Berbagai bukti menunjukkan bahwa virus Covid 19 penyebarannya paling utama melalui percikan (rute melalui droplet) dari sumber saluran pernapasan dan kegiatan kontak langsung dengan penderita. Kegiatan kontak langsung atau kontak erat dapat diartikan jika seseorang berjarak 1 meter dengan penderita yang terinfeksi. Rute droplet seperti melalui bersin, kontak sangat erat, batuk, sehingga masuk melalui titik-titik yaitu mata, hidung atau mulut. ${ }^{(2,3)}$ Fomit di lingkungan langsung orang yang terinfeksi dapat menjadi penyebaran virus Covid 19. ${ }^{(4,5)}$ Penyebaran virus Covid 19 bisa terjadi dalam bentuk kontak langsung dengan orang yang terinfeksi dan juga dapat menular secara tidak langsung dengan melalui kontak permukan lingkungan langsung atau pada benda yang digunakan oleh orang yang pernah mengalamai infeksi (terinfeksi), contohnya termometer dan stetoskop.

Persebaran Covid 19 di daerah Jawa Timur yaitu pada 19/5/2020 (Liputan6.com) dari 38 kabupaten terdapat 24 kabupaten di Jawa Timur yang mengalami perubahan zona Covid 19, dari zona merah menjadi zona kuning dan zona orange. Kabupaten Bangkalan tergolong Zona kuning. Kasus covid 19 di Jawa Timur masih terus bertambah. Pada 30/6/2020 sebanyak 389 orang pasien baru Covid 19. Sehingga pasien Covid 19 di Jawa Timur menjadi 12.118 orang. Surabaya merupakan penyumbang 210 pasien Covid 19 di Jawa Timur.

Dalam penyebaran Covid 19 bisa melalui aerosol walaupun tanpa prosedur yang menghasilkan aerosol atau AGP (aerosol-generating procedure) masih aktif diteliti oleh komunitas ilmuwan. Dalam beberapa penelitian ditemukan bahwa RNA virus dari fasilitasfasilitas klinis pada sampel udara dimana AGP tidak dilakukan. (6,7) tetapi penelitianpenelitian lain tidak $(4,5,8)$. RNA virus tidak dapat menginfeksi dan bereplikasi dan tidak mampu menyebar, RNA virus hanya menginokulasi, sehingga dapat menyebabkan infeksi yang invasif. Penelitian lain yang dilakukan menemukan virus RNA ${ }^{(9)}$ dan virus yang viable / hidup, akan tetapi penelitian-penelitian ini merupakan AGP eksperimen yang menghasilkan aerosol melalui nebulisator jet bertenaga tinggi dan tidak menunjukan kondisi batuk normal manusia.

Penularan Covid 19 diindikasikan bahwa penularan terjadi dari orang bergejala kepada orang lain yang dapat melalui kontak erat dan juga saat tidak menggunakan alat perlindungan diri (APD) yang tepat. RNA virus dapat terdeteksi setelah munculnya penyakit pada pasien bergejala atau simtomatik selama satu minggu. Pada pasien dengan gejala ringan pada hari ke delapan virus hidup tidak ditemukan $\mathbf{( 1 0 , 1 1 )}$, meskipun pada masa atau periode ini dapat lebih lama bagi pasien yang mengalami sakit parah. Namun, RNA shedding yang lebih lama tidak selalu bermakna berlanjutnya suatu sifat menginfeksi. Jumlah virus hidup yang dikeluarkan oleh seseorang baik melalui droplet atau batuk sangat mempengaruhi tingkat penularan atau transmissibility Covid 19. Penularan Covid 19 kemungkinan dapat terjadi dari orang-orang yang terinfeksi tetapi orang tersebut belum menunjukkan suatu gejala, jenis penularan ini disebut juga dengan jenis penularan prasimtomatik. Masa inkubasi Covid 19 atau waktu antara pajanan pada virus dan munculnya gejala kurang lebih 5 sampai dengan 6 hari, bisa juga terjadi sampai dengan 14 hari. ${ }^{(\mathbf{1 2}, 13)}$ Beberapa orang dapat diketahui positif Covid 19 dengan melalui tes PCR (polymerase chain reaction) 1 sampai dengan 3 hari sebelum muncul gejala. ${ }^{(14)}$

Transmisi atau penularan Covid 19 dari orang yang terinfeksi dan tidak mengalami gejala merupakan penularan prasimtomatik. Orang yang bergejala memiliki beban virus yang lebih tinggi pada saat atau bahkan sebelum munculnya suatu gejala. ${ }^{(15)}$ Proporsi kasus asimtomatik krang lebih 6\% - 41\% dan memberikan perkiraan gabungan sebesar $16 \%$ $(12 \% 20 \%) .{ }^{(16)}$ Virus yang hidup berhasil diisolasi dari spesimen-spesimen orang prasimtomatik maupun asimtomatik, oleh karenanya sehingga dapat mengindikasikan bahwa penyebaran virus Covid 19 dapat terjadi pada orang yang tidak mengalami gejala. (17)

Hasil yang telah didapatkan dari kegiatan posyandu pada tanggal $4-11$ September 2020 di Perum Griya Anugerah - Mlajah - Bangkalan - Kab. Bangkalan bahwasanya masih banyak ibu balita yang belum cukup mengetahui tentang pentingnya pemakaian masker pada balita, dan masih terdapat balita yang belum menggunakan masker dengan baik. Tujuan dari kegiatan ini yaitu untuk meningkatkan pengetahuan ibu tentang pentingnya penggunaan masker pada anak di masa wabah pandemi Covid 19. Kegiatan ini juga dilakukan agar dapat mencegah dari 
Dwi F.-Pemberdayaan Kader Posyandu Dalam Program Pencegahan Stunting Pada Balita di Masa Covid-19-hlm 7-14

penularan penyakit Covid 19. Kegiatan hal ini selain pemberian pengetahuan tentang penggunaan masker, juga disertai dengan pemberian masker pada anak dengan cara door to door.

\section{METODE}

Metode yang digunakan dalam kegiatan pengabdian masyarakat yaitu dalam bentuk:

a. Pemberian Edukasi atau pengetahuan tentang pentingnya pemakaian masker pada balita

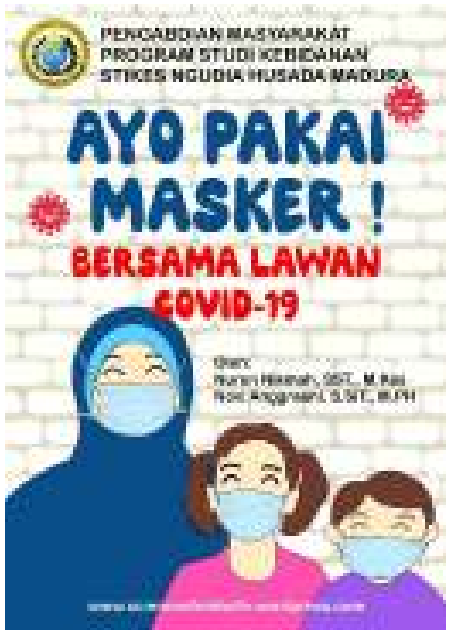

Gambar 1 Pentingnya penggunaan masker dan bagaimana pemasangan masker yang baik

b. Pemberian dan pemakaian Masker pada Anak/ Balita

Deskripsi: salah satu kegiatan untuk meningkatkan motivasi pada anak tentang penggunaan masker guna untuk mencegah tertularnya dan penularan Covid 19. Tujuan: untuk meningkatkan pengetahuan masyarakat tentang kegiatan bersama melawan covid 19 dengan cara penggunaan masker pada balita.

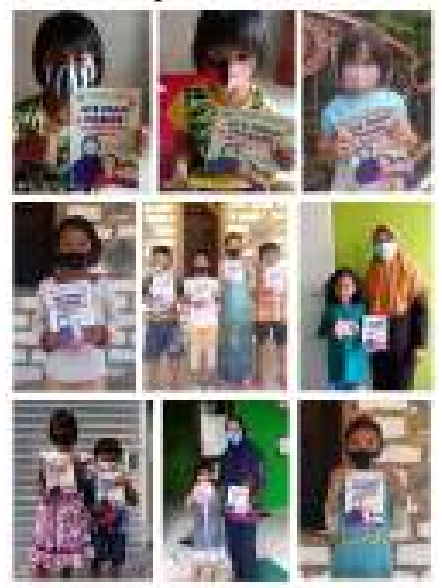

Gambar 2 Kegiatan pemberian masker dan pemakaian masker

\section{HASIL DAN PEMBAHASAN}

Pada saat proses kegiatan pemberian edukasi dan pemberian masker untuk bersama mencegah covid 19 telah dilaksanaan tanpa kendala. Segala persiapan untuk kegiatan ini termasuk persiapan masker, stiker/ pamflet, lembar edukasi, dan peralatan lain telah dipersiapkan oleh tim dengan sangat lengkap. Adapun hambatan atau kekurangan yang dialami pada pelaksanaan kegiatan yaitu berupa cakupan atau wilayah lokasi yang relatif kurang luas.

Tabel.1. Kegiatan Tim dalam Pengabdian

Masyarakat Desa Jaddih - Kec. Bangkalan

\begin{tabular}{|c|c|c|}
\hline No & $\begin{array}{l}\text { Tgl 4-11 } \\
\text { September } \\
2020\end{array}$ & Keterangan \\
\hline 1 & $\begin{array}{l}\text { Pemberian } \\
\text { Edukasi } \\
\text { tentang } \\
\text { "bersama } \\
\text { melawan covid } \\
19 \text { dengan } \\
\text { menggunakan } \\
\text { masker" }\end{array}$ & $\begin{array}{l}\text { Memberikan } \\
\text { edukasi pada } \\
\text { ibu balita } \\
\text { tentang: } \\
\text { 1. Pentingnya } \\
\text { penggunaan } \\
\text { masker } \\
\text { 2. Cara } \\
\text { memakai } \\
\text { masker yang } \\
\text { benar }\end{array}$ \\
\hline 2 & $\begin{array}{l}\text { Pemberian } \\
\text { Masker dan } \\
\text { edukasi } \\
\text { pemasangan } \\
\text { masker yang } \\
\text { baik } \\
\end{array}$ & $\begin{array}{l}\text { Kegiatan } \\
\text { pembagian atau } \\
\text { pemberian } \\
\text { masker pada } \\
\text { masing-masing } \\
\text { anak atau balita }\end{array}$ \\
\hline 3 & $\begin{array}{l}\text { Pemakaian } \\
\text { Masker pada } \\
\text { Balita }\end{array}$ & $\begin{array}{l}\text { Mempraktikkan } \\
\text { pemasangan } \\
\text { masker pada } \\
\text { anak sehingga } \\
\text { diharapkan } \\
\text { anak dapat } \\
\text { menggunakan } \\
\text { masker dengan } \\
\text { baik }\end{array}$ \\
\hline
\end{tabular}

Berikut adalah grafik pemakaian masker sebelum dan sesudah diberikan edukasi 


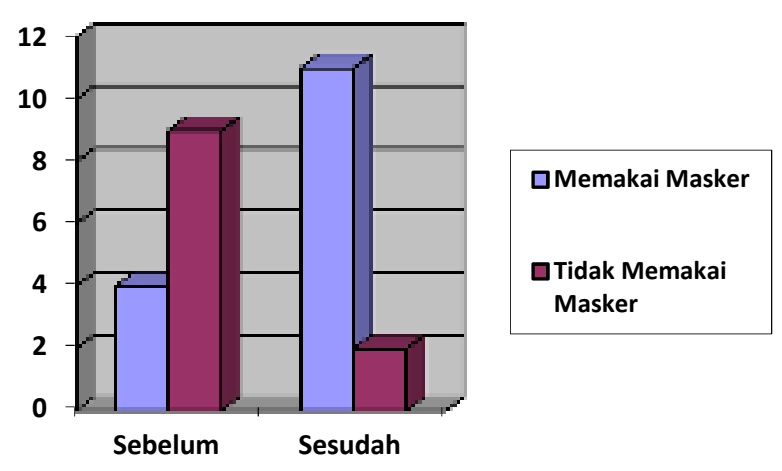

Gambar 2 Grafik terhadap Perbandingan Pengetahuan

Tabel 1 Kegiatan Tim dalam Pengabdian Masyarakat Gerakan Ayo Pakai Masker

\begin{tabular}{ccc}
\hline Pengetahuan & $\begin{array}{c}\text { Pemakaian } \\
\text { Masker }\end{array}$ & $\begin{array}{c}\text { Tidak Memakai } \\
\text { Masker }\end{array}$ \\
\hline Sebelum & $4(30,77 \%)$ & $11(84,62 \%)$ \\
\hline Sesudah & $\begin{array}{c}9 \\
(69,23 \%)\end{array}$ & $2(15,38 \%)$ \\
\hline & $13(100 \%)$ & $13100 \%)$
\end{tabular}

\section{KESIMPULAN}

1. Berdasarkan analisis situasi, masalah stunting menjadi masalah utama di Desa Kutisari Leran Kecamatan Manyar Gresik

2. Kader Posyandu tetap bisa melakukan edukasi / penyuluhan kepada masyarakat khususnya ibu ibu balita dusun Kutisari, dengan media daring/online atau secara tatap muka namun dengan ketentuan protokol kesehatan yang ketat sesuai anjuran dari pemerintah

3. Kader Posyandu mendapatkan edukasi tentang :

a. Pembuatan media edukasi seperti : video, whatsapp grup, leaflet, dan buku saku

4. Leaflet dan Buku Saku untuk Kader Posyandu sebagai alat peraga Penyuluhan tentang Stunting pada Balita, diharapkan dapat menjadi alat peraga yang bermanfaat dan kader posyandu dapat memberikan edukasi kepada masyarakat sesuai dengan standar dari pemerintah.

5. Hasil monitoring dan evaluasi dari kegiatan pengabdian masyarakat ini, didapatkan hasil adanya peningkatan pengetahuan Kader Posyandu
6. Dari Kegiatan Masyarakat ini didapatkan hasil, yakni penurunan angka stunting balita di Desa Kutisari Kecamatan Manyar.

\section{SARAN}

Keterbatasan dalam melakukan kegiatan pengabdian, dan hanya diimplementasikan di satu Desa. Harapan tim pada kegiatan pengabdian masyarakat selanjutnya dapat mencakup wilayah dan sasaran yang lebih besar, sehingga manfaat kegiatan pengabdian masyarakat ini juga bisa dirasakan oleh masyarakat luas.

\section{DAFTAR PUSTAKA}

1 UNICEF. Convention on the Rights of the Child text. 1990 (https://www.unicef.org/child-rightsconvention/convention- text

2 Liu J, Liao X, Qian S, Yuan J, Wang F, Liu Y, et al. Community Transmission of Severe Acute Respiratory Syndrome Coronavirus 2, Shenzhen, China, 2020. Emerg Infect Dis. 2020;26(6):13203.

3 Coronavirus disease 2019 (COVID-19) Situation Report - 73. Jenewa: World Health Organization; 2020

(https://www.who.int/docs/defaultsource/corona viruse/situation-reports/20200402-sitrep73covid-19.pdf?sfvrsn=5ae25bc7_6

4 Cheng VCC, Wong SC, Chen JHK, Yip CCY, Chuang VWM, Tsang OTY, et al. Escalating infection control response to the rapidly evolving epidemiology of the coronavirus disease 2019 (COVID-19) due to SARS-CoV2 in Hong Kong. Infect Control Hosp Epidemiol. 2020;41(5):4938

5 Ong SWX, Tan YK, Chia PY, Lee TH, Ng OT, Wong MSY, et al. Air, Surface Environmental, and Personal Protective Equipment Contamination by Severe Acute Respiratory Syndrome Coronavirus 2 (SARS-CoV-2) From a Symptomatic Patient. JAMA. 2020.

6 Guo ZD, Wang ZY, Zhang SF, Li X, Li L, Li C, et al. Aerosol and Surface Distribution of Severe Acute Respiratory Syndrome Coronavirus 2 in Hospital Wards, Wuhan, China, 2020. Emerg Infect Dis. 2020;26(7). 
Dwi F.-Pemberdayaan Kader Posyandu Dalam Program Pencegahan Stunting Pada Balita di Masa Covid-19-hlm 7-14

7 Santarpia JL, Rivera DN, Herrara V, Morwitzer MJ, Creager H, Santarpia GW, et al. Transmission Potential of SARS-CoV-2 in Viral Shedding Observed at the University of Nebraska Medical Center. medRxiv.

8 Faridi S, Niazi S, Sadeghi K, Naddafi K, Yavarian J, Shamsipour M, et al. A field indoor air measurement of SARS-CoV-2 in the patient rooms of the largest hospital in Iran. Sci Total Environ. 2020;725:138401.

9 van Doremalen N, Bushmaker T, Morris DH, Holbrook MG, Gamble A, Williamson BN, et al. Aerosol and Surface Stability of SARS-CoV-2 as Compared with SARS-CoV-1. N Engl J Med. 2020;382(16):1564-7.

10 Fears A, Klimstra W Duprex P, et al. Comparative dynamic aerosol efficiencies of three emergent coronaviruses and the unusual persistence of SARS-CoV-2 in aerosol suspensions (pracetak). MedRxiv. [pracetak].https://www.medrxiv.org/content/10. $1101 / 2020.04 .13 .20063784 \mathrm{v} 1$

11 Symptom-Based Strategy to Discontinue Isolation for Persons with COVID-19. Atlanta: Centers for Disease Control and Prevention; (https://www.cdc.gov/coronavirus/2019ncov/co mmunity/strategy-discontinue-isolation.html).

12 Wolfel R, Corman VM, Guggemos W, Seilmaier M, Zange S, Muller MA, et al. Virological assessment of hospitalized patients with COVID2019. Nature. 2020;581(7809):465-9.

13 Yu P, Zhu J, Zhang Z, Han Y. A Familial Cluster of Infection Associated With the 2019 Novel Coronavirus Indicating Possible Person-toPerson Transmission During the Incubation Period. J Infect Dis. 2020;221(11):1757-61.

14 Lauer SA, Grantz KH, Bi Q, Jones FK, Zheng Q, Meredith HR, et al. The Incubation Period of Coronavirus Disease 2019 (COVID-19) From Publicly Reported Confirmed Cases: Estimation and Application. Ann Intern Med. 2020;172(9):577-82.

15 Kimball A, Hatfield KM, Arons M, James A, Taylor J, Spicer K, et al. Asymptomatic and Presymptomatic SARS- CoV-2 Infections in
Residents of a Long-Term Care Skilled Nursing Facility - King County, Washington, Maret 2020. MMWR Morb Mortal Wkly Rep. 2020;69(13):377-81.

16 He X, Lau EHY, Wu P, Deng X, Wang J, Hao X, et al. Temporal dynamics in viral shedding and transmissibility of COVID-19. Nat Med. 2020;26(5):672-5.

17 Byambasuren, O., Cardona, M., Bell, K., Clark, J., McLaws, M.-L., Glasziou, P., 2020. Estimating the extent of true asymptomatic COVID-19 and its potential for community transmission: systematic review and metaanalysis (pracetak). Infectious Diseases (except HIV/AIDS). MedRxiv. [pracetak].(https://www.medrxiv.org/content/10. $1101 / 2020.05 .10 .20097543 \mathrm{v} 1$

18 Arons MM, Hatfield KM, Reddy SC, Kimball A, James A, Jacobs JR, et al. Presymptomatic SARS-CoV-2 Infections and Transmission in a Skilled Nursing Facility. N Engl J Med. 2020;382(22):2081-90. 